\title{
Reconstruction and Application of the Biochemistry Curriculum System in Local Universities
}

\author{
Ji Lusha and Guo Shangjing \\ College of Life Science, Liaocheng University, *Corresponding Author: Ji Lusha (1982 - ) \\ Liaocheng, China \\ E:mail:jilusha@1cu.edu.cn
}

\begin{abstract}
Combining the construction and application of biochemistry curriculum system in local universities, we summarize the significance, construction goals and implementation plan to construct the biochemistry online open curriculum in local colleges and universities. Our research will provide reference for the construction of biochemistry curriculum system in local Universities.
\end{abstract}

Keywords—Biochemistry Curriculum System, Application, Local Universities

\section{INTRODUCTION}

Biochemistry is the core curriculum for biology-related majors. It is a multidisciplinary curriculum in biology, medicine, pharmacy and agronomy. According to their own various educational objectives and development orientations, China's universities possess varied focuses in the construction of biochemistry curriculum system [1]. Taking the basic biochemistry curriculum as the core, the construction of biochemistry curriculum system in local universities sets characteristic biochemistry curriculum system according to the characteristics of each major development. The curriculums within the system possess the overall teaching requirements and modular teaching contents, and then the curriculums in group can better reflect the organic permeability, overlapping and integration, and fully exhibit the strength of the curriculum group [2]. In recent years, the reconstruction of biochemistry curriculum system is mainly embodied in the following five aspects: (1) It formulates a reasonable curriculum system and teaching syllabus. The curriculum system and teaching syllabus conform to the characteristics of local universities. (2)It optimizes and reconstructs the curriculum contents within curriculum system in local universities. (3)It focuses on reforming the teaching methods and teaching means of biochemistry curriculum in local universities. (4)It reforms the experimental system and strengthens the practice teaching. (5)It reforms the evaluation and examination methods.

\section{EASE OF USE}

\section{A. The Significance of Reconstructing Biochemistry Curriculum System in Local Universities}

To achieve the reconstruction of biochemistry curriculum system in local universities, and to put forward ideas and solutions on problems arising from the construction of high-level applied key majors in universities, the significance of reconstructing the biochemistry curriculum system in local universities lies in:

1) Based on the construction of high-level applied major for the biochemistry curriculum teaching system in local universities.

It discusses the position, the construction of teaching materials and the reform of cutting-edge teaching methods for biochemistry curriculum in the development of subjects in local universities. It guarantees that the construction of biochemistry curriculum in local universities can truly meet the actual needs of students and truly realize point to point teaching. It combines the scientific quality cultivation and the career quality plan of students in biochemistry majors, and then becomes a significant platform for cultivating applied talents. It also hopes to call on more teachers from related biological majors in local universities to devote themselves to the construction of biochemistry curriculum researches.

2) The construction of biochemistry curriculum system in local universities puts forward the need to reconstruct 


\section{biochemistry curriculum system.}

It reconstructs the content system, teaching syllabus, applicable teaching materials and teaching methods of biochemistry curriculum system in local universities. It clarifies the knowledge structure of biochemistry curriculum that students from biochemistry major in local universities should grasp. Besides, it solves the general phenomenon like disjunctions of "teaching" and "learning" as well as "test" and "application" in current biochemistry curriculum education.

3) The biochemistry curriculum system in local universities has built the foundation through years of teaching and practical experiences.

Combining the characteristics of current biological education and academic foreland, it deeply analyzes the key innovation of biochemistry curriculum in biology teaching, and then it designs and develops related teaching projects and pilot projects of "biochemistry curriculum system" for undergraduate students in biology major. Besides, it targets to increase "biochemistry" knowledge of students in biology major. Thus, it hopes to cultivate "versatile" talents who can not only master the solid professional knowledge in biology major, but possess a wealth of knowledge in the field of biological applications.

\section{B. The Goal of Constructing Biochemistry Curriculum System in Local Universities}

1) Reconstruction of High-level Applied Majors for the Biochemistry Curriculum Teaching System in Local Universities

It constructs a biochemistry curriculum system suitable for the characteristics of local universities. The curriculum teaching system includes "Basic Biochemistry + Advanced Biochemistry + Biochemistry Course Frontier + Biochemistry Experiment Technology". It respectively develops teaching syllabus and write "Analysis Report of High-Level Applied Majors for the Biochemistry Curriculum System in Local Universities".

2) Construction of Distinctive Teaching Materials for Biochemistry Curriculum System Suitable for Local Undergraduate Universities

Over the past decade, China's biochemistry teaching materials have achieved rapid development. There are more than 500 copies of textbooks issued by official publishers, including 136 copies of biochemistry experiment textbooks and 29 copies of learning instructional monographs. Is the construction of biochemistry teaching materials for high-level applied majors in local universities in line with the characteristics of their own majors, teachers' levels, students' qualities and academic platform? Should we consider the basic biological levels of students from high-level applied majors in local universities and add more contents for biochemistry forefronts and experiment results? Should we compile a distinctive teaching material? The teaching material should be in line with the actual level of biochemistry curriculum for high-level applied majors in local universities and in line with their actual needs. Besides, the teaching material differs from majors.

3) A Study on Teaching Contents and Methods by Combining Biochemistry Curriculum Teaching and Professional Education of High-level Applied Majors in Local Universities

The goal of the biochemistry curriculum construction in local universities is to separate majors and largely cultivate students. It focuses on the reform of teaching practice and explores a teaching method. The teaching method can reflect various major characteristics and meet the needs of various major developments. Biochemistry curriculum in local universities should reflect the differences of various major training objectives, especially for the particularity of the applied major construction in local universities. It also should conform to the goal of cultivating high-quality applied talents. Therefore, the combination of biochemistry teaching and professional education is even more urgent. The combination of the biochemistry and students' professional literacy, the biochemistry and academic frontier, the biochemistry curriculum and curriculum application under the application background in universities allow students to apply their knowledge and become high-quality professional talents.

4) Creating High-quality Online Curriculum Platform for the Community to Achieve Lifelong Education through MOOC / SPOC Platform

Through the blended curriculum construction model of MOOC (Massive Open Online Course is large-scale 
online courses) and SPOC (Small Private Online Course is a small restrictive course), China integrates quality domestic online education resources, and then provides better learning experience on online biochemistry platform for students ${ }^{[3]}$. Besides, it applies the platform of high-quality curriculum construction in local universities to build high-quality online biochemistry curriculum platform. The high-quality online biochemistry curriculum platform is in line with its own professional training objectives. Ultimately, it constructs high quality online biochemistry curriculum group for lifelong education of the community.

\section{Reform Scheme Design of Biochemistry Curriculum System in Local Universities}

\section{1) Reform and Construction of Biochemistry Curriculum System}

The focus on the construction of biochemistry curriculum system is to improve and integrate the whole curriculum content according to the characteristics of biology, agriculture, pharmacy and medicine in universities. After a systematic study of biochemistry curriculum, a series of biochemistry curriculums are proposed and established.

\section{a)On Teaching Links}

Basic Biochemistry Curriculum: It opens for biology and related subjects in universities, and it's the basic curriculum opened for the second year undergraduate students. It's divided into animal biochemistry, medical biochemistry and agricultural biochemistry.

Molecular Biochemistry Curriculum: It opens for biology and related subjects in universities, and it's the basic curriculum opened for the second year undergraduate students. On the basis of basic biochemistry curriculum, it lectures on professional knowledge of molecular biology.

Advanced Biochemistry Curriculum: It opens for biology and related subjects in universities, and it's the optional curriculum opened for the third year undergraduate students. On the basis of basic biochemistry curriculums, it conducts teaching according to majors and levels.

Biochemistry Frontier topics: It opens for biology and related subjects in universities, and it's the optional curriculum opened for the fourth year undergraduate students. It introduces biochemistry frontier knowledge and provides guidance for postgraduate examination.

\section{b) Testing Teaching Links}

Basic Biochemistry Experiment Technology One (8 class hours) Separation purification and detection technology of proteins and nucleic acids.

Animal Biochemistry Internship Two (8 class hours) Examples of glucose metabolism, lipid metabolism and amino acid metabolism.

Molecular Biochemistry Internship Three (8 class hours) Key technology in the process of DNA replication, transcription and translation.

Comprehensive Design Test (24 class hours)

Biochemistry experiments in local universities are taught as a separate curriculum. It possesses 48 class hours. It requires undergraduate students not only to complete basic skills training experiments, but also to actively participate in exploratory and innovative researches and opening experiments (Table I). It hopes students can master the academic frontier theoretical knowledge and foster experimental abilities with independent innovation. 
TABLE I. BIOCHEMISTRY EXPERIMENT CURRICULUM SYSTEM IN LOCAL UNIVERSITIES (PARTIAL EXPERIMENTAL PROJECTS)

\begin{tabular}{|c|c|c|c|}
\hline Test Items & Contents & Class Hours & Test Type \\
\hline The Amount of Sugar & $\begin{array}{l}\text { Learn the principles of sugar determination and the } \\
\text { application of spectrophotometers }\end{array}$ & 3 & Confirmatory \\
\hline $\begin{array}{l}\text { Determination of Fat Iodine } \\
\text { Value }\end{array}$ & $\begin{array}{l}\text { Understand the significance of the determination for fat } \\
\text { iodine value, conduct analysis and evaluation combined } \\
\text { with commonly used oil in daily life }\end{array}$ & 3 & Confirmatory \\
\hline $\begin{array}{l}\text { Paper Chromatography of } \\
\text { Amino Acids }\end{array}$ & $\begin{array}{l}\text { Understand the principle of amino acid separation, master } \\
\text { the basic operation of paper chromatography }\end{array}$ & 3 & Confirmatory \\
\hline Preparation of Casein & $\begin{array}{l}\text { Master the method of extraction of protein by isoelectric } \\
\text { point precipitation method, learn the use of acidity meter }\end{array}$ & 3 & Confirmatory \\
\hline $\begin{array}{c}\text { Preparation of Amylase Crude } \\
\text { Extraction }\end{array}$ & $\begin{array}{l}\text { Learn about the principles and methods of ammonium } \\
\text { sulfate precipitation of proteins, master dialysis and } \\
\text { freeze centrifugation }\end{array}$ & 3 & Confirmatory \\
\hline $\begin{array}{c}\text { Separation and Component } \\
\text { Identification of YEAST RNA }\end{array}$ & $\begin{array}{l}\text { Master the methods of identifying nucleic acid } \\
\text { components and yeast culture }\end{array}$ & 3 & Confirmatory \\
\hline $\begin{array}{c}\text { Detecting Protein Concentration } \\
\text { by } \mathrm{CBB}\end{array}$ & $\begin{array}{l}\text { Master the basic skills of Coomassie Brilliant Blue } \\
\text { (CBB) to determine protein concentration }\end{array}$ & 3 & Confirmatory \\
\hline $\begin{array}{c}\text { Acetic Acid Cellulose } \\
\text { Membrane Electrophoresis of } \\
\text { Serum Protein }\end{array}$ & $\begin{array}{l}\text { Learn the operation of cellulose acetate membrane } \\
\text { electrophoresis, understand the principle of } \\
\text { electrophoresis }\end{array}$ & 3 & Confirmatory \\
\hline Determination of $\mathrm{Vc}_{\mathrm{c}}$ Content & \multirow{4}{*}{$\begin{array}{l}\text { Independently look up relevant literatures, select } \\
\text { materials, be familiar with the usage of instruments, } \\
\text { complete the experiment design and submit the } \\
\text { experiment report }\end{array}$} & 6 & Designable \\
\hline $\begin{array}{l}\text { Determination of Reductase } \\
\text { Activity for Lamina Acetic } \\
\text { Acid }\end{array}$ & & 6 & Designable \\
\hline $\begin{array}{c}\text { Extraction and Characterization } \\
\text { of Nucleic Acid }\end{array}$ & & 6 & Designable \\
\hline $\begin{array}{l}\text { Preparation and Property } \\
\text { Identification of Chitosan }\end{array}$ & & 6 & Designable \\
\hline
\end{tabular}

\section{2) Distinctive Teaching Material Reform of Biochemistry Curriculum}

In the course of years of biochemistry teaching, universities would like to improve teaching quality, and ensure that students can fully grasp the basic knowledge of biochemistry and maintain the continuous updating of knowledge and master academic foreland [4]. Therefore, it's necessary to compile a series of biochemistry curriculum teaching materials and develop offline teaching software to accord with the applied major in local universities. Some chapters of related biochemistry materials edited by biochemistry curriculum teaching team are showed as following (Table II). 
TABle II. Directory of BIOChemistry Materials (PARTIAL ChaPters)

\begin{tabular}{|c|c|c|}
\hline Article & Chapter & Section \\
\hline \multirow{2}{*}{\multicolumn{2}{|c|}{ Introduction }} & The First Quarter Introduction of Biochemistry \\
\hline & & The Second Quarter Development of Biochemistry \\
\hline \multirow{19}{*}{$\begin{array}{c}\text { Article One } \\
\text { Structural } \\
\text { Biochemistry }\end{array}$} & \multirow{9}{*}{$\begin{array}{l}\text { Chapter One } \\
\text { Biochemistry of } \\
\text { Protein }\end{array}$} & The First Quarter The Molecular Composition of the Protein \\
\hline & & The Second Quarter The Primary Structure of the Protein \\
\hline & & The Third Quarter The Secondary Structure of the Protein \\
\hline & & The Fourth Quarter Super Secondary Structure and Structure City \\
\hline & & The Fifth Quarter The Tertiary Structure of Protein Molecules \\
\hline & & The Sixth Quarter The Quaternary Structure of the Protein \\
\hline & & The Seventh Quarter The Relationship Between Protein Structure and Function \\
\hline & & The Eighth Quarter Physicochemical Properties of Protein \\
\hline & & The Ninth Quarter Separation, Purification and Identification of Proteins \\
\hline & \multirow{4}{*}{$\begin{array}{l}\text { Chapter Two } \\
\text { Biochemistry of } \\
\text { Nucleic Acid }\end{array}$} & The First Quarter The Spatial Structure of DNA \\
\hline & & $\begin{array}{l}\text { The Second Quarter Some Physicochemical Properties and Commonly used } \\
\text { research methods of Nucleic Acid }\end{array}$ \\
\hline & & The Third Quarter Biosynthesis of DNA and RNA \\
\hline & & The Fourth Quarter Biosynthesis of the Protein \\
\hline & \multirow{6}{*}{$\begin{array}{l}\text { Chapter Three } \\
\text { The principle of } \\
\text { Enzyme Action }\end{array}$} & The First Quarter Two Hypotheses of the Combination of Enzymes and Substrates \\
\hline & & The Second Quarter The Essence and Mechanism of Enzymatic Reaction \\
\hline & & The Third Quarter Kinetics of Enzyme Reaction \\
\hline & & The Fourth Quarter Allosteric Enzymes and Allosteric Regulation \\
\hline & & The Fifth Quarter Enzyme \\
\hline & & The Sixth Quarter Introduction of Enzyme Program \\
\hline
\end{tabular}

3) Reforming Teaching Methods to Achieve the Form and Purpose of Flexible Usage

a) Teachers utilize emotional encouragement and other teaching methods to constantly keep students interested in biochemistry and maintain enthusiasm for biochemistry.

The interactions between teacher and students are established, while teachers must improve their own scientific literacy and professional basic skills. First of all, teachers should make full preparation before class, especially in teaching methods and styles. Second, teachers should try their efforts to create excellent study environments for students in class and after class. Besides, teachers should stimulate the enthusiasm of students to learn biochemistry and make them feel the fun of biochemistry learning. Ultimately, students are cultivated to possess biological literacy and love life science.

b) Through role exchange between teacher and students, the teacher should make shredded lesson preparation and ask questions before class, while students should make repeated surveys and look up materials before class.

For example, metabolic biochemistry has been the most difficult part for students to understand, we take the method to dismantle the metabolic steps, and then gradually put them together and teach students. We show a variety of laws to the students. At this time, students will feel metabolic biochemistry is stiff to learn.

c) Through heuristic teaching method and question discussions, the latest scientific research achievements and curriculum contents are combined to achieve "scientific research nurturing teaching, teachers leading the growth".

The chief curriculum instructor can integrate years of scientific research achievements into the teaching, and then effectively combine the teaching stages of biochemistry with academic foreland. The instructor can cultivate the interests of the second year students in biological science researches in local universities, and then lay the curriculum 
foundation for the students' postgraduate entrance exams in future. Besides, what should be paid attention to is that: Teachers should learn more about how the other members of the teaching team analyze scientific research problems and understand a concept. Moreover, teachers should emphasize the introduction of new experimental technologies and methods.

d) It focuses on the combination of lecturing in class and self-study after class. The curriculum ideas, knowledge structure, curriculum focus and difficulties of biochemistry should be intensively taught.

In the course of each biochemistry curriculum, students are arranged to study the contents by themselves, while the contents are emphasized to the students in the next lesson, meanwhile, the students are asked questions.

e) The biochemistry curriculum is implemented methods of framework-based memory. Teachers assist students to draw biochemistry curriculum system.

The framework-based memory of "structure - nature - function" is implemented in the static biochemistry aspect. The framework-based memory of "glucose metabolism - lipid metabolism - amino acid metabolism" is implemented in the dynamic biochemistry aspect. The framework-based memory of "replication - transcription - translation" is implemented in molecular biochemistry aspect.

4) Application and Teaching Reform of Modern Educational Technology in Biochemistry Teaching

a) There are two ways to develop the multimedia courseware resources of the biochemistry curriculum system in local universities: one is to download a large amount of online resources.

According to the characteristics of the local universities, most of them choose to utilize them directly. The other is that due to various characteristics of majors in local universities, teachers make certain courseware chapters according to professional characteristics and their own scientific research advantages. At present, a series of biochemical boutique courseware are developed in local universities and are presented in the school biochemistry boutique page. It ultimately achieves full multimedia network teaching and effectively helps students to understand the focuses and difficulties of the curriculum.

b) The biochemistry team in local universities target to the development of animation resources, and then the deep and difficult knowledge becomes visualized and specific (especially in experimental teaching of biochemistry).

Common biochemistry animations are "Glycolytic Pathway", "Tricarboxylic Acid Cycle", "Electron Transport Chain", "Chemosmotic Hypothesis", "the Central Dogma of Genetic Information" and so on. These resources are more visualized and vivid so that students can understand these biological processes.

c) Biochemistry curriculum system can be implemented widespread bilingual teaching. It is the direction that our teaching and research team have always insisted on.

It's also the overall direction of domestic biochemistry curriculum system. The biochemistry curriculum is the most closely integrated curriculum with scientific frontier, so it possesses relatively higher requirements on English [5]. In order to achieve the bilingual teaching of the curriculum, we divide it into a few steps: the first step is to bilingual the key terms of each chapter in the existing teaching network resources. The second step is to implement limited bilingual teaching method in the "Basic Biochemistry" curriculum, and then constantly optimize the usage of bilingual teaching courseware and lay the early foundation for bilingual teaching. The third step is to select a class in the senior grade for a small range of "Advanced Biochemistry" bilingual teaching, and then promote it depending on the situation.

d) Local universities apply multimedia teaching model of "network teaching + multimedia classroom teaching + personal tutorship" in the biochemistry curriculum reform.

It seizes the leading advantage of domestic MOOC/SPOC development, and then builds a platform for online open biological curriculum. The platform helps local universities to form their own teaching characteristics. It solves the construction of biochemistry network curriculum system in local universities. Besides, it puts forward the idea and scheme of constructing online biochemistry curriculum [6]. Through the research on the construction of MOOC/SPOC blended curriculum, it builds a special advantageous platform of professional online open courses in local universities, and reaches the domestic advanced level in the field of the industry.

"The reconstruction and application of high-level applied key construction for professional biochemistry 
curriculum teaching system in local universities" should focus on the construction of biochemistry theory curriculum system and the experimental curriculum system of biochemistry comprehensive development in local universities. Through the establishment of these innovative curriculums, it can effectively cultivate the biology theory and experiment level of biology-related professional students. The application of practice teaching enables students to possess clear direction for their future studies and stimulate their innovation abilities. Besides, students can actively show themselves. Thus, it promotes the development and progress of China's biology.

\section{ACKNOWLEDGEMENTS}

Fund Program: Quality Curriculum Construction Project of Postgraduate in Shandong Province (Lu Degree [2017] NO.1): Education Innovation Program of Postgraduate in Shandong Province (NO. SDYY15016)

\section{REFERENCES}

[1] Y.J. Wang, “The Practical Explore on Biochemistry Educational Reform, ” Biology teaching, 2012, vol. 29(5), pp. 100-105.

[2] S.F. Xu, "On the Construction of Applied Curriculum System for Newly-established Local Universities against the Background of Transition," Vocational and Technical Education, 2015, vol. 35 (36), pp. 20-22.

[3] W. Xu, "From MOOC to SPOC: Lessons from MOOC at Tsinghua and UC Berkeley", Modern Distance Education Research, 2014, vol. 4, pp. 13-22.

[4] B. Li, "Reconstructing Curriculum System of Local University on the Basis of Cultivating Mode", Educational Research, 2011, vol. 8, pp. 379-382.

[5] Y.L. Feng, "Research on the Construction of Teaching Team Based on Biochemistry Curriculum Group in University", Research On Education Tsinghua University, 2014, vol. 1, pp. 85-93.

[6] Y.Q. Kang, “An Analysis on SPOC: Post - MOOC Era of Online Education”, Research On Education Tsinghua University, 2014, vol. 3, pp. $85-93$. 